\title{
Amazighopsidae, a new family of decapod macruran astacideans from the late Cretaceous (Cenomanian-Turonian) of Gara Sbaa, Southeastern Morocco
}

\author{
Alessandro Garassino ${ }^{1^{*}}$, Giovanni Pasini ${ }^{2}$
}

\begin{abstract}
We investigate a new decapod macruran discovered in deposits identified at the top of Gara Sbaa slope, located in SE Morocco, along the "Hamada des Kem Kem", close to the Algerian border. These fossiliferous levels are known in the literature as part of the Late Cretaceous Kem Kem beds. We report the new family Amazighopsidae, created to accommodate Amazighopsis cretacica n. gen., n. sp. Indeed, some morphological characters, such as a short rostrum with the serrate upper margin, cervical and antennal grooves not forming the characteristic W-shaped pattern, the telson without diaeresis, lateral margins of the telson with one movable median spine and two movable distal spines, and the uropodal exopod without diaeresis, are so peculiar and unique to justify the erection of the new family tentatively ascribed to the infraorder Astacidea.
\end{abstract}

Key words: Crustacea, Decapoda, Astacidea, Late Cretaceous, Morocco.

Riassunto - Amazighopsidae, una nuova famiglia di decapodi macruri astacidi del Cretacico superiore (Cenomaniano-Turoniano) del Gara Sbaa, Marocco sudorientale.

Viene descritto un nuovo decapode macruro rinvenuto nei depositi identificati nella parte sommitale della scarpata del Gara Sbaa, localizzata nel Marocco sudorientale, lungo 1"'Hamada des Kem Kem", in prossimità del confine algerino. Questi livelli fossilifieri sono conosciuti in letteratura come facenti parte della serie dei "Kem Kem beds" e attribuiti al Cretacico superiore. Viene descritta la nuova famiglia Amazighopsidae che comprende Amazighopsis cretacica n. gen., n. sp. Alcuni caratteri morfologici, quali il corto rostro con margine superiore denticolato, i solchi cervicale e antennale non disposti a formare una caratteristica $\mathrm{W}$, il telson senza dieresi e margini laterali con una spina mobile mediana e due spine mobili distali e l'esopode dell'uropode privo di dieresi, sono esclusivi ed unici da giustificare la nuova famiglia, che viene tentativamente ascritta all'infraordine Astacidea.

Parole chiave: Crustacea, Decapoda, Astacidea, Cretacico superiore, Marocco.

${ }^{1}$ Sezione di Paleontologia degli Invertebrati, Museo di Storia Naturale, Corso Venezia 55, 20121 Milano, Italia.

${ }^{2}$ Via Alessandro Volta 16, 22070 Appiano Gentile (Como), Italia. E-mail: juanaldopasini@tiscali.it

*Corresponding author: alessandro.garassino@comune.milano.it; alegarassino@gmail.com

(C) 2018 Alessandro Garassino, Giovanni Pasini

Received: 24 August 2017

Accepted for publication: 13 October 2017

\section{INTRODUCTION}

We investigate a new macruran discovered in deposits identified at the top of Gara Sbaa slope (Garassino et al., 2008; Cavin et al., 2010; Martill et al., 2011), located in SE Morocco, along the "Hamada des Kem Kem", close to the Algerian border. These fossiliferous levels are known in the literature as the Upper Cretaceous Kem Kem beds (Sereno et al., 1996). The sediments forming a wide arc emerge from NE to SE for a distance of $250 \mathrm{~km}$ and are marked on the $\mathrm{N}$ by Tafilalt area, on the $\mathrm{E}$ by "Hamada du Guir", on the S by "Hamada des Kem Kem", and on the $\mathrm{W}$ by Precambrian formations and Paleozoic of AntiAtlas. The studied area, located SW of Taouz, $26 \mathrm{~km} \mathrm{S-}$ SW of Tafraout (on the western border of Hamada), along the Oued Sbaa, consists of a poorly exposed sedimentary series, located at the top of a small mesa, known as Gara Sbaa (for locality map, see Garassino et al., 2008, 38, Fig. 1; Cavin et al., 2010, Fig. 2; Martill et al., 2011, Figs. 1 and 2). The Kem Kem beds rest unconformably on Paleozoic deposits. They are divided into two units (lower and upper units) (Choubert, 1948), with a total thickness of $200 \mathrm{~m}$ (Lavocat, 1954). The non-marine lower unit includes dinosaur bed-bones, whereas the upper unit is comprised of sandstones, detrital channels, clay-beds, and a dinosaur track key bed on the top (Garassino et al., 2006). The upper unit is covered by marine deposits of platform (limestones) of the Cenomanian-Turonian transgression. Sereno et al. (1996) and Dutheil (2000) suggested a Cenomanian age for the Kem Kem beds corresponding to the "Infracénomanien" by Clariond (1933) based upon the palaeontological data (elasmobranch biostratigraphy), lacking radiometric and magnetostratigraphic survey.

The Pre-African platform of Morocco was the subject of geomorphologic analysis in some localities between Erfoud and Errachidia (200 km to N of Kem Kem beds), above all on Cenomanian and Turonian deposits. The lithology and faunal assemblage suggest an environment of an inshore lagoon during Albian-Cenomanian ages, with the formation of an enclosed proximal reef on a wide platform during the Cenomanian-Turonian time (Ettachfini \& Andreu, 2004). In particular, the Aoufous Formation is probably the lithologic equivalent of the upper unit of the Kem Kem beds, Albian-Cenomanian in age (Ettachfini \& Andreu, 2004). Finally, the authors pointed out that the lower part of the Akrabou Formation, in the Kem Kem ba- 
sin, is late Cenomanian in age based upon the presence of Neolobites vibrajeanus and the ichthyofauna assemblage (Basse \& Choubert, 1959). Previously, Cavin \& Dutheil (1999) suggested a probable late Cenomanian age for the ichthyofauna assemblages discovered in the area of Daoura (upper Kem Kem beds), not far from the studied locality. Another locality, located on the western margins of the Kem Kem beds area, "close to Gara Sbaa", was presumed to be Cenomanian in age, without detailed investigation (Garassino et al., 2006).

The new sedimentary levels, covering the upper unit of the Kem Kem beds corresponding to the Kem Kem "compound assemblage" sensu Cavin et al. (2010), lay directly on the Cenomanian-Turonian limestones. Garassino et al. (2008), lacking stratigraphic and sedimentological data, proposed Cenomanian-Turonian ages for these Lagerstätte laminate levels, according to direct field observations. Cavin et al. (2010: 403-404), "pending additional fieldwork", continue to refer these carbonate beds to the "Agoult assemblage" (Akrabou Fm.), probably having a Cenomanian or early Turonian age. As reported by Martill et al. (2011) the lack of calcareous fossils makes it difficult to establish the precise age of the deposit. Although the Gara Sbaa Lagerstätte is probably late Cenomanian or early Turonian in age, the lack of strata overlying the laminites does not allow establishing a minimum age for this locality. Based upon these observations, we refer the faunal assemblage to the Cenomanian-Turonian in a general way. The fossiliferous levels, having a limited exposure (about $500 \mathrm{sq} \mathrm{m}$ ) and $1.80 \mathrm{~m}$ thickness, show at the base sublithographic laminated limestones (60-70 cm thick), including a rich faunal assemblage, including, in addition to decapod crustaceans, xiphosurans, isopods, tanaideacean peracarids, rare insects, traces of marine worms, rare pelagic crinoids, rare teeth of chondrichthyes lamniformes, one ray, many well-preserved specimens of actinopterygians and many indeterminate specimens of amiiformes (Garassino et al., 2008; Cavin et al., 2010; Martill et al., 2011; Murray \& Willson, 2011; Vernygora \& Murray, 2015), and just one very rare lizard (Pasini, pers. obs., 2013). Finally, wellpreserved florula consisting of leafy branches and leaves also have been discovered (Krossilov \& Bacchia, work in progress). A limited assemblage of insects was also reported by Engel et al. (2012). All fossil specimens have a high level of preservation and they are usually articulated, resembling the same taphonomic signature of other "Lagerstätten" quarries.

\section{Previous reports of decapod crustaceans from Gara Sbaa}

Dutheil (1999) reported the presence of decapod crustaceans in the faunal assemblage of a locality "close to Gara Sbaa", in the upper part of the Kem Kem beds of a Cenomanian age. Garassino et al. (2006) described Cretapenaeus berberus Garassino, Pasini \& Dutheil, 2006, a freshwater decapod crustacean, based upon specimens gathered by Dutheil from this locality. Later, Guinot et al. (2008) and Garassino et al. (2008) reported a rich assemblage of macrurans, brachyurans, and anomurans from a new fossiliferous locality, discovered at the top of Gara Sbaa escarpment and referred to the Late Cretaceous (Cenomanian-Turonian). These reports increased the knowledge of decapod crustaceans from the Late Cretaceous of Morocco, as follows: Glyphea garasbaaensis Garassino, De Angeli \& Pasini, 2007 (Glypheidae Zittel, 1885), Corazzatocarcinus cfr. C. hadjoulae (Roger, 1946) (Necrocarcinidae Förster, 1968), Telamonocarcinus cfr. T. gambalatus Larghi, 2004 (Telamonocarcinidae Larghi, 2004), Galathea sahariana Garassino, De Angeli \& Pasini, 2008 (Galatheidae Samouelle, 1819), Paragalathea africana Garassino, De Angeli \& Pasini, 2008, and Cretagalathea exigua Garassino, De Angeli \& Pasini 2008 (Munidiae Ahyong, Baba, Macpherson \& Poore, 2010). Finally, some specimens of eubrachyurans not showing strict correlations with any crabs known to date, were assigned to Marocarcinidae Guinot, De Angeli \& Garassino, 2008, with Marocarcinus pasinii Guinot, De Angeli \& Garassino, 2008. Recently, Garassino et al. (2014) erected Muelleristhes Garassino, De Angeli \& Pasini, 2014 (Catillogalatheidae Robins, Feldmann, Schweitzer \& Bonde, 2016) to accommodate Paragalathea africana.

\section{MATERIALS AND METHODS}

Three complete specimens in lateral view, housed in the palaeontological collections of the Museo di Storia Naturale di Milano (MSNM). The specimens were careful cleaned mechanically, and photographed both by natural and UV illumination to emphasize phosphatized exoskeleton parts.

Abbreviations - lcpx: length of carapace (including rostrum); ldi: length of P1dactylus and index; lp: length of P1 palm; P1-P5: pereiopods 1 to 5; s1-s6: pleonal somites 1 to 6 ; tl: total length; wcpx: width of carapace; wp: width of P1 palm.

\section{SYSTEMATIC PALAEONTOLOGY}

\author{
Infraorder Astacidea Latreille, 1802 \\ Section Indeterminate \\ Family Amazighopsidae nov.
}

Diagnosis: Carapace subcylindrical; triangular, short rostrum with serrate suprarostral margin, bearing 3-4 pairs of teeth; deep cervical groove strongly inclined forward, reaching the dorsal margin at the anterior third of the total carapace length (excluding rostrum); antennal groove short and weak; cephalic region shorter than branchial one; s1 short; s2 with subrounded pleura partially overlapping those of s1 and s3; s1, s3-s6 smooth with rounded pleurae; subrectangular telson without diaeresis and lateral margins with one median movable spine and two distal movable spines; chelate P1 with weak heterochely; uropodal exopod without diaeresis.

Type and included genus: Amazighopsis n. gen., by monotypy.

Etymology: From Amazigh that means Berber in the original language of this people. 
Geological range: Late Cretaceous (CenomanianTuronian).

Discussion. Some morphological characters of the studied specimens, such as the dorso-laterally compressed carapace, the cylindrical shape of the carapace, and the strong chelate P1 allow us to assign them tentatively to the infraorder Astacidea, including all the marine chelate lobsters. Indeed the assignment to this infraorder is tentative because, according to Karasawa et al. (2013: 110), some other diagnostic characters, such as the rostrum with supra- and subrostral teeth, s2 larger than s3-s6, and the uropodal exopod with diaeresis do not fit with the characters of the studied specimens.

According to Karasawa et al. (2013: 94) the new classification for lobsters, after the phylogenetic systematics proposed by Scholtz \& Richter (1995) and Wahle et al. (2012), includes two sections for the infraorder Astacidea Latreille, 1802, as follows: Homarida Scholtz \& Richter, 1995 and Astacida Scholtz \& Richter, 1995. The former includes three superfamilies, Enoplometopoidea de Saint Laurent, 1988 (Enoplometopidae de Saint Laurent, 1988; Uncinidae Beurlen, 1930); Stenochiroidea Beurlen, 1928 (Stenochiridae Beurlen, 1928); and Nephropoidea Dana, 1852 (Nephropidae Dana, 1852). The latter includes three superfamilies, Protastacoidea Albrecht, 1983 (Protastacidae Albrecht, 1983); Astacoidea Latreille, 1802 (Astacidae, Latreille, 1802; Cambaridae Hobbs, 1942; Cricoidoscelosidae Taylor, Schram \& Yan-Bin, 1999); and Parastacoidea Huxley, 1879 (Parastacidae Huxley, 1879), truly " ...poorly known in the fossil record." (Karasawa et al., 2013).

Though the two sections have substantial morphological differences concerning the rostrum (short or elongate with supra- or subrostral teeth), the carina and groove system of the carapace, the pleon (pleurae more or less pointed or rounded), and the telson (with or without diaeresis), they share one constant and consistent diagnostic character, the uropodal exopod with diaeresis, according to the most recent phylogenetic systematics proposed by Karasawa et al. (2013).

Based upon the diagnoses proposed by Karasawa et al. (2013) for each family within the two sections, we point out that some morphological characters of the studied specimens, such as the strongly tuberculate carapace and $\mathrm{P} 1$; a short rostrum with serrate suprarostral margins, bearing 3-4 pairs of teeth; a deep cervical groove and a weak antennal groove not forming the characteristic "W" shape; s2 with subrounded pleura partially overlapping those of s1 and s3; smooth s1, s3s6 with rounded pleurae; a subtrapezoidal telson without diaeresis and lateral margins with one median movable spine and two distal movable spines; chelate P1 slightly heterochelous (peculiar shape of the P1 chela: P1 index occlusal margin with a row of strong rounded teeth inclined forward and arranged randomly; P1 dactylus occlusal margin with a row of pointed, elongate, and slender teeth strongly inclined distally); and mainly the uropodal exopod without diaeresis, are so unique and peculiar that the studied specimens do not fit any diagnosis for known clawed lobster families, provided by the authors.
Therefore, these differences warrant a distinct family within the Astacidea to accommodate the type genus Amazighopsis n. gen.

The new family cannot be assigned to both sections of the infraorder Astacidea based upon the characters proposed by Karasawa et al. (2013: 110, 113). According to Holthuis (1991: 31-47; fig. 61), the new family may be, however, tentatively assigned to the section Homarida based upon Nephropsis Wood-Mason, 1873, the sole genus within this section, including the extant species with or without a diaeresis on the uropodal exopod. Moreover, the lack of the diaeresis on the telson in the new family, a peculiar character of the Homarida, as proposed by Karasawa et al. (2013: 116) (vs. telson with diaeresis in Astacida), would further support the assignment of the new family to this section.

\section{Genus Amazighopsis nov.}

Diagnosis: as for family.

Type species: Amazighopsis cretacica $\mathrm{n}$. gen., n. sp., by monotypy.

\section{Amazighopsis cretacica n. gen., n. sp.} Figs. 1-6

Diagnosis: as for family.

Etymology: the trivial name alludes to the Cretaceous, the geological age of the studied specimens.

Holotype: MSNM i27545.

Paratypes: MSNM i27546, MSNM i27646.

Type locality: Gara Sbaa (Kem Kem).

Material and measurements: three complete specimens, one of these (MSNM i27546) preserved as part and counterpart.

MSNM i27545 - tl: $45 \mathrm{~mm}$; lcpx: $25 \mathrm{~mm}$; wcpx: $12 \mathrm{~mm}$; lp: $10 \mathrm{~mm}$; wp: $7 \mathrm{~mm}$; ldi: $8 \mathrm{~mm}$

MSNM i27546 - tl: $65 \mathrm{~mm}$; lp: $10 \mathrm{~mm}$; wp: 7 mm; ldi: $9 \mathrm{~mm}$

MSNM i27646 - lp: 10 mm; wp: 7 mm; ldi: 9 $\mathrm{mm}$

Description. Carapace - Subcylindrical carapace strongly granular, laterally compressed; dorsal margin slightly convex; posterior margin nearly straight; triangular, short rostrum with serrate suprarostral margin, bearing 4-5 pairs of teeth; dorsal rostral surface concave without median carina; subrostral margin spineless; deep cervical groove nearly straight, strongly inclined forward, reaching the dorsal margin at the anterior third of the total carapace length (excluding rostrum), making an angle of about $45^{\circ}$ to the dorsal margin; antennal groove short and weak; cephalic region shorter than branchial one; branchiocardiac, postcervical, and hepatic grooves absent; carapace surface without accessory spines. Pleon $-\mathrm{s} 1$ short, narrow; s2 with subrounded pleura partially overlapping those of $\mathrm{s} 1$ 

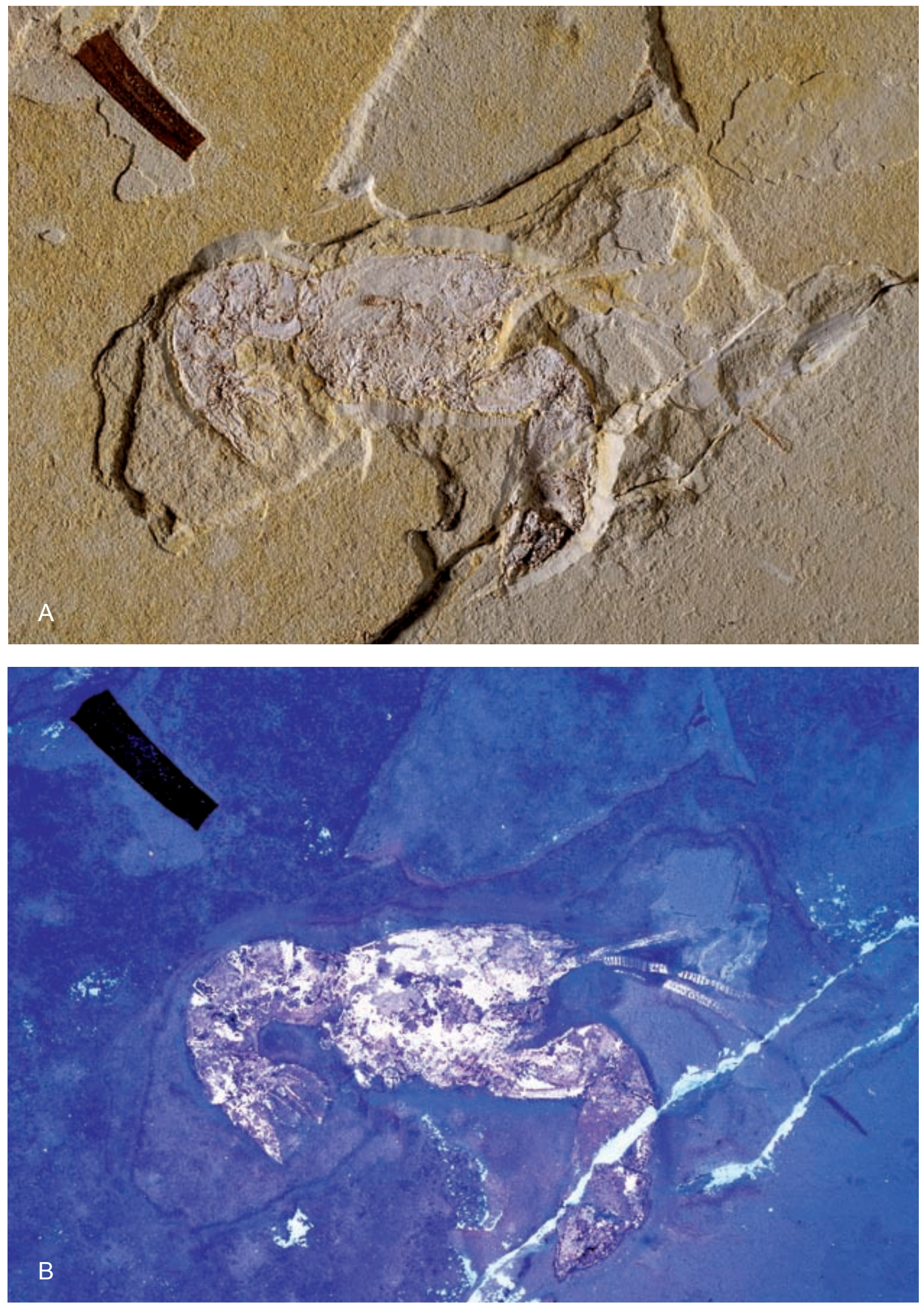

Fig. 1 - Amazighopsis cretacica n. gen., n. sp., MSNM i27545, Holotype. A) General view in natural light (x 1.51). B) General view in UV light (x 1.44). 
and s3; convex pleurae, slightly rounded ventrally, ending in a short point; tergites and pleurae of s1-s6 smooth; subtrapezoidal telson without diaeresis, and lateral margins with one median movable spine and two distal movable spines. Cephalic appendages - Cephalic appendages poorly preserved, flagella of antennulae and antennae partially preserved; antennae flagella stronger than those of the antennulae. Thoracic appendages - mpx3 and P2-P5 not preserved; P1 slightly heterochelous, with ischium, merus, carpus, and propodus strongly granulate; right P1 with squared ischium, subrectangular elongate merus, convex and serrate dorsally; stout subtriangular carpus with serrate dorsal margin; elongate subrectangular chela serrate dorsally, outer surface with two parallel longitudinal rows of strongly aligned tuberculate spines; right P1 chela with elongate dactylus and index, equal in length
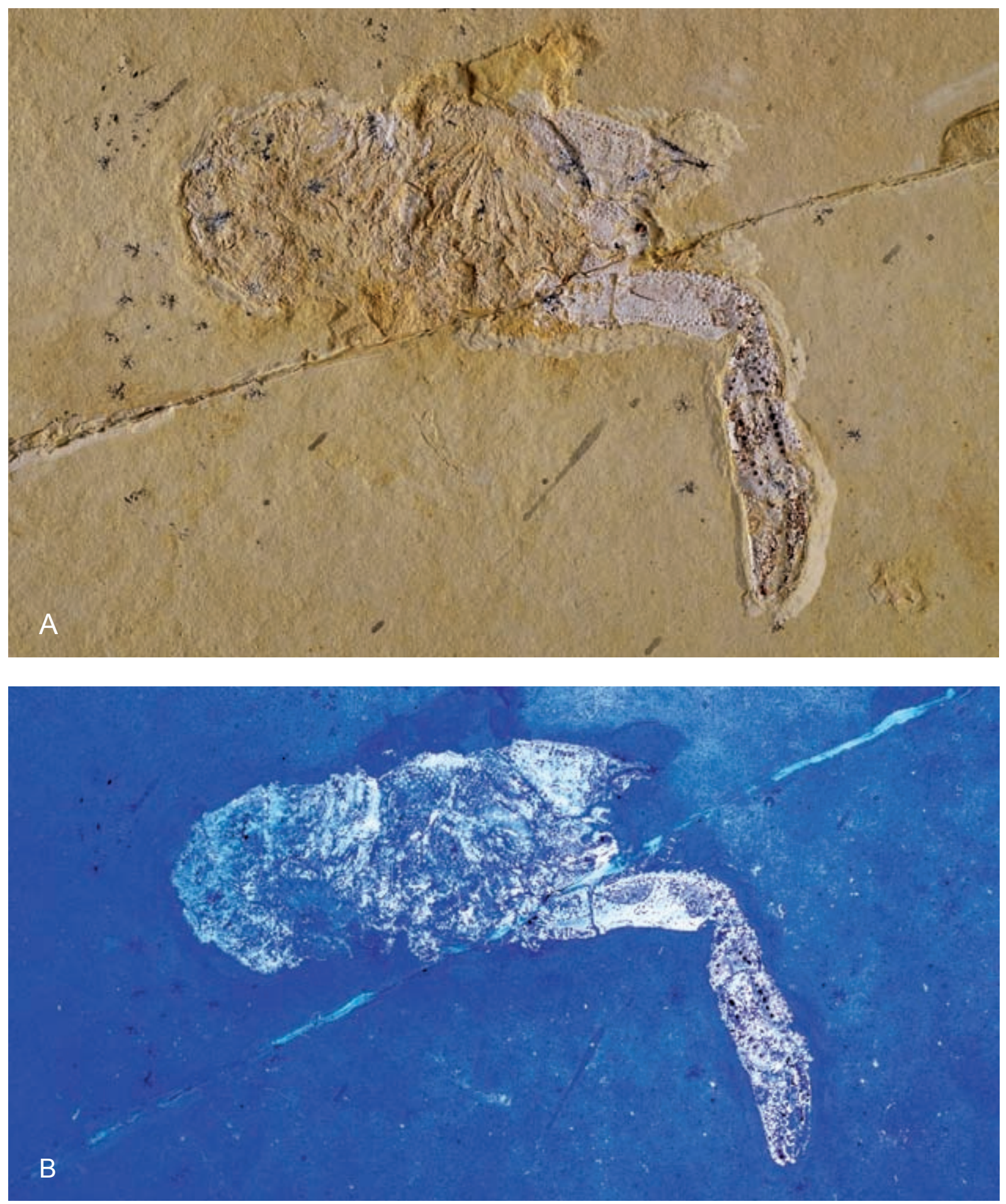

Fig. 2 - Amazighopsis cretacica n. gen., n. sp., MSNM i27546, Paratype. A) General view in natural light (x 1.23). B) General view in UV light (x 1.12). 
and curved distally; index slightly stronger than dactylus; index occlusal margin with a row of strong, rounded molariform teeth inclined distally and arranged randomly; dactylus occlusal margin, with a row of pointed, elongate, and slender teeth strongly inclined distally; left $\mathrm{P} 1$ propodus, merus, and carpus similar in shape and ornamentation of right P1; left chela poorly preserved, looks slightly stouter than the right with stronger index and dactylus, occlusal margins bearing a rim of similar rounded molariform teeth. Pleonal appendages - Pleopods poorly preserved; uropodal endopod and exopod as long as telson; uropodal endopod and exopod rounded posteriorly with one thin longitudinal median carina and spiny margins; uropodal exopod without diaeresis.
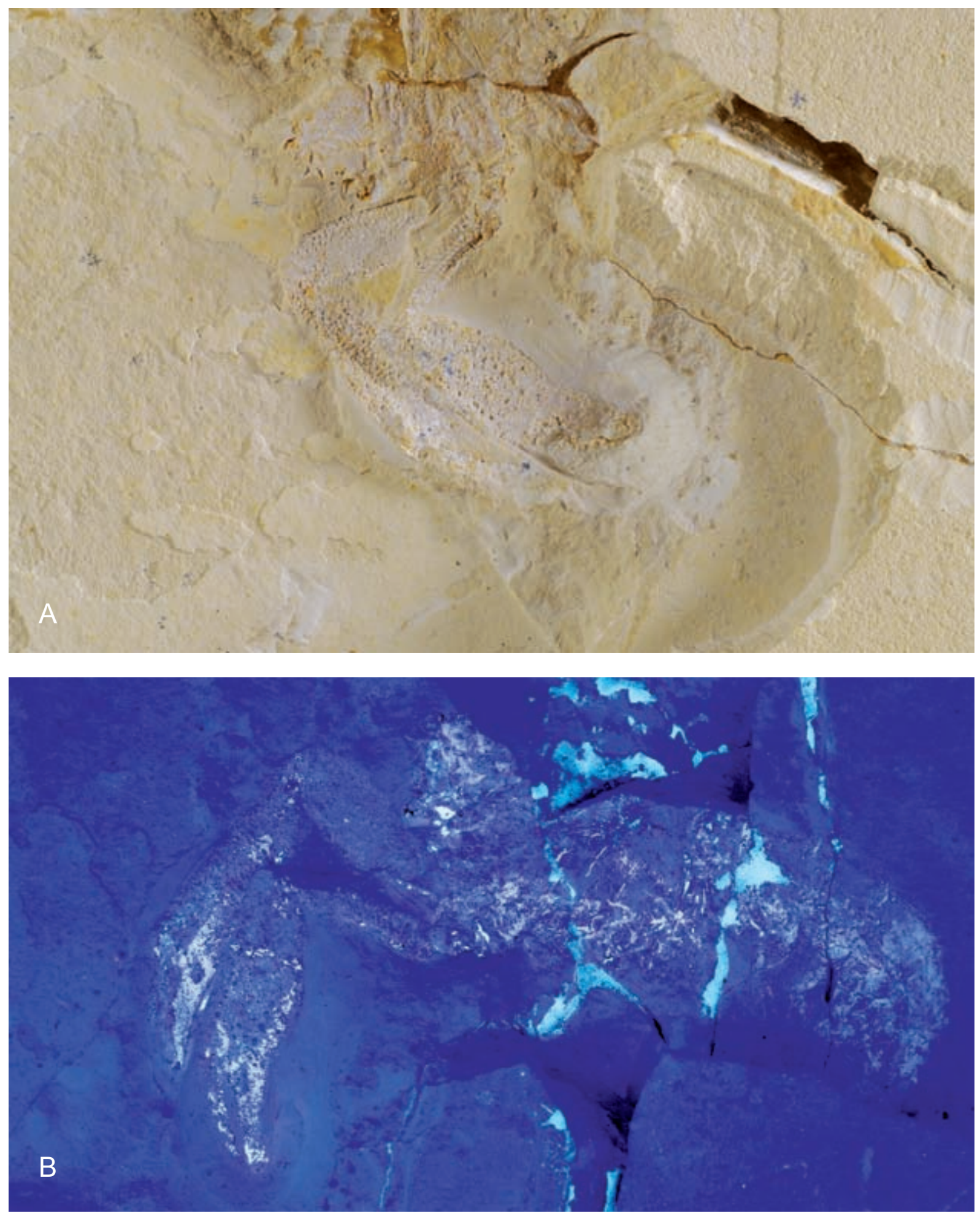

Fig. 3 - Amazighopsis cretacica n. gen., n. sp., MSNM i27646, Paratype. A) General view in natural light (x 2). B) General view in UV light (x 1.71). 


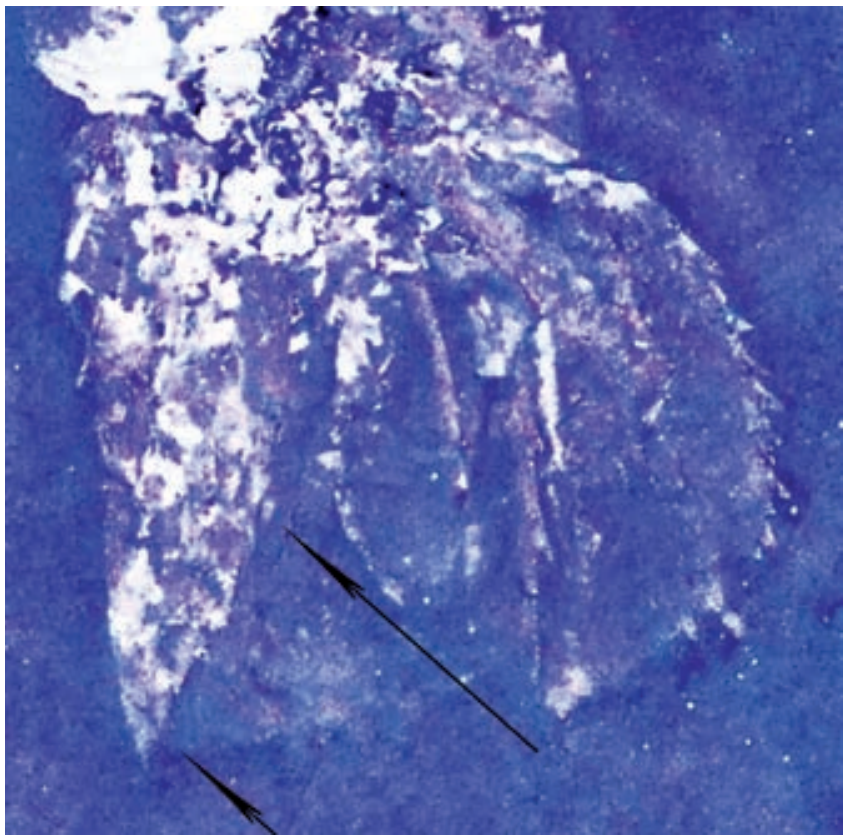

Fig. 4 - Amazighopsis cretacica n. gen., n. sp., MSNM i27545, close-up of the telson without diaeresis and with movable spines on lateral margin (arrows) and uropodal exopod without diaeresis (x 6.81).
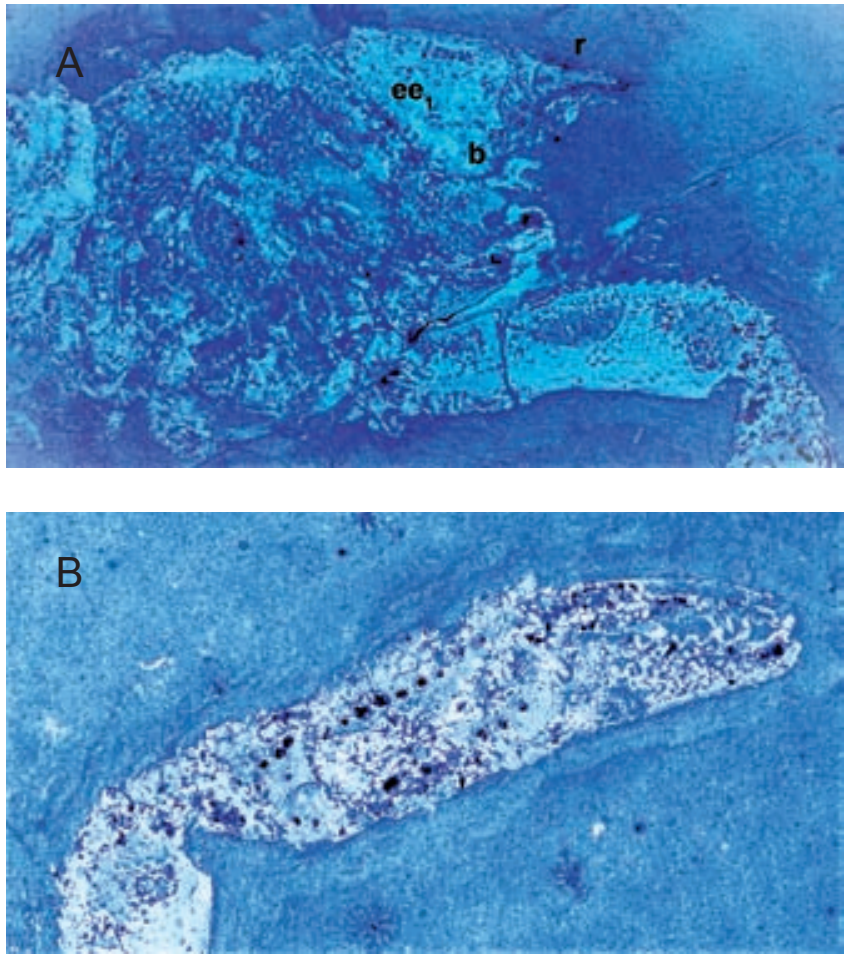

Fig. 5 - Amazighopsis cretacica n. gen., n. sp., MSNM i27546. A) Close-up of the carapace with the simple system grooves [cervical, $\left(e_{1}\right)$ and antennal (b) grooves] and short rostrum with serrate suprarostral margin (x 1.36). B) Close-up of P1 chela with the occlusal margins of dactylus and index (x 1.78).

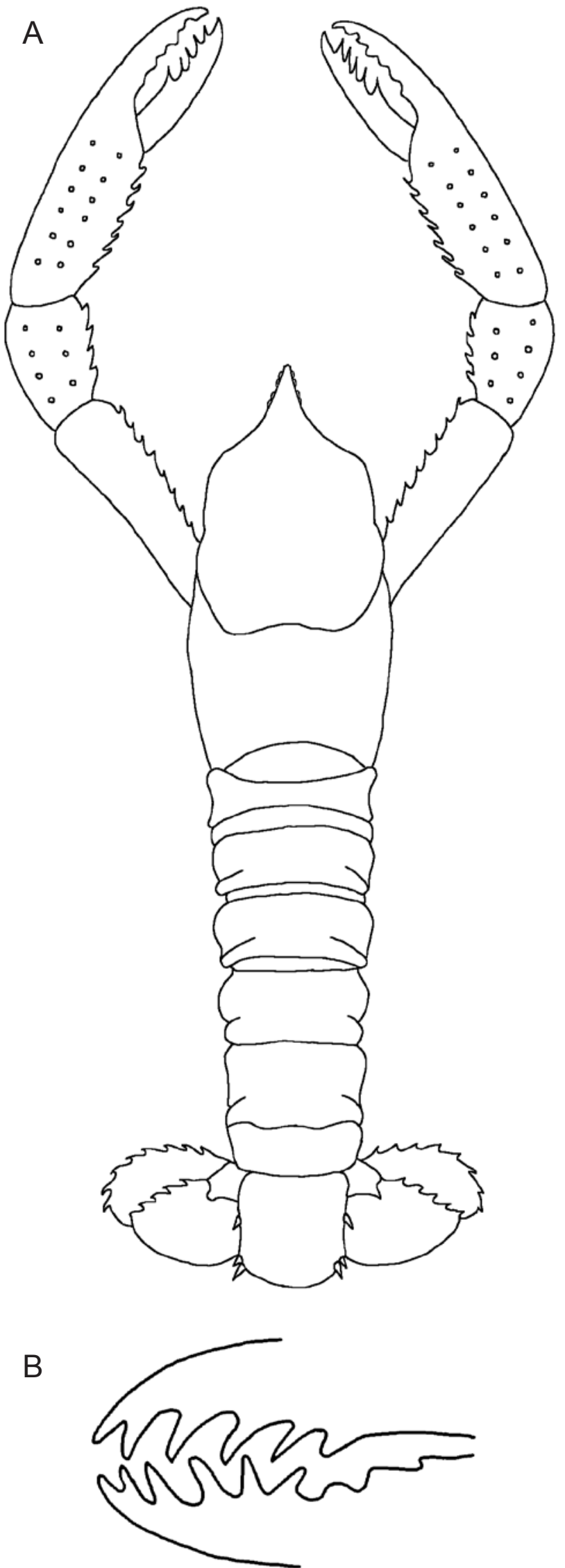

Fig. 6 - Amazighopsis cretacica n. gen., n. sp. A) reconstruction. B) close-up of the occlusal margins of P1 chela. 


\section{Acknowledgements}

We wish to thank Giorgio Teruzzi, Sezione di Paleontologia degli Invetebrati, Museo di Storia Naturale, Milano (Italy), for the photos of the studied specimens, Rodney M. Feldmann, Department of Geology, Kent State University, Kent, OH (U.S.A.), and Hiroaki Karasawa, Mizunami Fossil Museum, Yamanouchi, Akeyo, Mizunami, Gifu (Japan) for careful review and criticism.

\section{REFERENCES}

Basse E. \& Choubert G., 1959 - Les faunes d'ammonites du "Cénomano-Turonien" de la partie orientale du domaine atlasique marocain et des ses annexes sahariennes. Congreso Geologico Internacional XX Sesion. Ciudad de Mexico, 1956. Symposium del Cretàcico: 59-82.

Cavin L. \& Dutheil D.B., 1999 - A new Cenomanian ichthyofauna from southeastern Morocco and its relationships with other early Late Cretaceous Moroccan faunas. Geologie en Mijnbouw, The Netherlands, 78: 261-266.

Cavin L., Tong H., Boudad L., Meister C., Piuz A., Tabouelle J., Aarab M., Amiot R., Buffettaut E., Dyke G., Hua S. \& Le Loeuff J., 2010 - Vertebrate assemblages from the early Late Cretaceous of southeastern Morocco: An overview. Journal of African Heart Sciences, 57: 391-412.

Choubert G., 1948 - Essai sur la paléogéographie du Mesocrétacé marocain. Société des Sciences naturelles du Maroc, 1920-1945: 307-329.

Clariond L., 1933 - Les terrains primaires et la Hammada de Taouz (Confins algéro-marocains du Sud). Compterendu sommaire des Séances de la Société géologique de France, Paris, 1933 (2): 47-48.

Dutheil D.B., 1999 - An overview of freshwater fish fauna from the Kem Kem beds (Late Cretaceous: Cenomanian) of southeastern Morocco. In: Mesozoic Fishes 2. Systematics and the fossil Record. Arratia G. \& Schultze H.P. (eds). Verlag Dr. Friederich Pfeil.

Dutheil D.B., 2000 - Les Cladistia du Cénomanien continental du Sud-est marocain et les ichthyofaunes associées. Implications biostratigraphiques, taphonomiques, paléoécologiques et paléobiogéographiques. $D i$ plôme de l'Ecole Pratique des Hautes Etudes, Unpublished degree. Paris.

El Ettachfini M. \& Andreu B., 2004 - Le Cénomanien et le Turonien de la Plateforme Préafricaine du Maroc. Cretaceous Research, 25: 277-302.

Engel M.S., McKellar R.C., Gibb S. \& Chatterton B.D.E., 2012 - A new Cenomanian-Turonian (Late Cretaceous) insect assemblage from southeastern Morocco. Cretaceous Research, 35: 88-93.

Garassino A., De Angeli A. \& Pasini G., 2008 - New decapod assemblage from the Upper Cretaceous (Cenomanian-Turoanian) of Gara Sbaa, southestern Morocco. Atti della Società italiana di Scienze naturali e del Museo civico di Storia naturale in Milano, 149 (1): 37-67.
Garassino A., De Angeli A. \& Pasini G., 2014 -A new porcellanid genus (Crustacea, Decapoda) to accomodate the Late Cretaceous Paragalathea africana Garassino, De Angeli \& Pasini, 2008 from southeast Morocco. In: Proceedings of the $5^{\text {th }}$ Symposium on Mesozoic and Cenozoic Decapod Crustaceans, Krakow, Poland, 2013: A tribute to pal Mihaly Müller. Fraaje, R.H.B., Hyžný, M., Jagt, J.W.M., Krobicki, M. \& Van Bakel, B.W.M. (eds.). Scripta Geologica, 147: 117-124.

Garassino A., Pasini G. \& Dutheil D. B., 2006 - Cretapenaeus berberus n. gen., n. sp. (Crustacea: Decapoda: Penaeidae) from the Late Cretaceous (Cenomanian) of Southeastern Morocco. Atti della Società italiana di Scienze naturali e del Museo civico di Storia naturale in Milano, 147 (1): 3-17.

Guinot D., De Angeli A. \& Garassino A., 2008 - Marocarcinidae, a new eubrachyuran family, and Marocarcinus pasinii $\mathrm{n}$. gen., n. sp. from the Upper Cretaceous (Cenomanian-Turonian) of Gara Sbaa, southeastern Morocco (Crustacea, Decapoda, Brachyura). Atti della Società italiana di Scienze naturali e del Museo civico di Storia naturale in Milano, 149 (1): 25-36.

Holthuis L. B., 1991 - FAO species catalogue. 13. Marine lobsters of the world. Food and Agriculture Organization of the United Nations, Rome.

Karasawa H., Schweitzer C.E. \& Feldmann R.M. 2013 - Phylogeny and systematics of extant and extinct lobsters. Journal of Crustacean Biology, 33 (1): 78-123.

Lavocat R., 1954 - Reconaissance géologique dans les hammadas des confines algéro-marocains du Sud. Notes et Mémoires du Service géologique du Maroc, 116: $1-148$.

Martill D., Ibrahim N., Brito P. M., Baider L., Zhouri S., Loveridge R., Naish D. \& Hing R., 2011 - A new Plattenkalk Konservat Lagerstätte in the Upper Cretaceous of Gara Sbaa, south-eastern Morocco. Cretaceous Research, 32: 433-446.

Murray A.M. \& Wilson M.V.H., 2011 - A new species of Sorbinichthys (Teleostei: Clupeomorpha: Ellimmichthyiformes) from the late Cretaceous of Morocco. $\mathrm{Ca}$ nadian Journal of Earth Sciences, 48 (1): 1-9.

Scholtz G. \& Richter S., 1995 - Phylogenetic systematics of the reptantian Decapoda (Crustacea, Malacostraca). Zoological Journal of the Linnean Society, 113: 289328.

Sereno P.C., Dutheil D.B., Iarochène M., Larsson H.C.E., Lyon G.H., Magwene P.M., Sidor C.A., Varricchio D.J. \& Wilson J.A., 1996 - Predatory dinosaurs from the Sahara and Late Cretaceous faunal differentiation. Science, 272: 986-991.

Vernygora O. \& Murray A.M., 2015 - A new species of Armigatus (Clupeomorpha, Ellimmichthyiformes) from the Late Cretaceous of Morocco, and its phylogenetic relationships. Journal of Vertebrate Paleontology, e1031342. doi: 10.1080/02724634.2015.1031342

Wahle R.A., Tshudy D., Cobb J.S., Factor J. \& Jaini M., 2012 - Infraorder Astacidea Latreille, 1802 p.p.: the marine clawed lobsters. In: Treatise on Zoology, Anatomy, Taxonomy, Biology. Schram F.R. \& von Vaupel Klein J.C. (eds.). The Crustacea, 9 (B): 3-108. 